\title{
Geochemical Characterization and Mineralogy of Babouri-Figuil Oil Shale, North-Cameroon
}

\author{
Alexis Jacob Nyangono Abolo ${ }^{*}$, Simon Ngos III' ${ }^{2}$, Augustin Desire Balla Ondoa ${ }^{3}$, \\ Bruno Garcia', Maria Fernanda-Sarmiento ${ }^{4}$, Olive Cecile Mbesse ${ }^{5}$, Guy Martin Abolo6, \\ Daniel Mackaire Eloung Nna1, Augustin Ephraim Nkengfack ${ }^{1}$, Emmanuel Ndjeng1, \\ Jialin Qian ${ }^{7}$ \\ ${ }^{1}$ Faculty of Sciences, University of Yaounde I, Yaounde, Cameroon \\ ${ }^{2}$ Faculty of Sciences, University of Maroua, Maroua, Cameroon \\ ${ }^{3}$ Faculty of Sciences, University of Ngaoundere, Ngaoundere, Cameroon \\ ${ }^{4}$ Geosciences Division, Institut Français du Pétrole, Energies Nouvelles (IFPEN), Rueil-Malmaison, France \\ ${ }^{5}$ Faculty of Sciences, University of Douala, Douala, Cameroon \\ ${ }^{6}$ National Hydrocarbons Corporation, Yaounde, Cameroon \\ ${ }^{7}$ Department of Chemistry, China University of Petroleum, Beijing, China \\ Email: alexis abolo@yahoo.com, sngos@yahoo.com, ankengf@yahoo.fr, elnad2006@yahoo.fr, \\ bruno.garcia@ifpen.fr, maria-fernanda.romero-sarmiento@ifpen.fr, mbesse2001@yahoo.fr, \\ augustelecompte2007@yahoo.fr, $\underline{\text { mg abolo@yahoo.fr, jlqian2001@yahoo.com }}$
}

Received 4 September 2014; revised 1 October 2014; accepted 17 October 2014

Copyright (C) 2014 by authors and Scientific Research Publishing Inc.

This work is licensed under the Creative Commons Attribution International License (CC BY).

http://creativecommons.org/licenses/by/4.0/

c) (i)

Open Access

\begin{abstract}
Organic geochemistry methods such as high temperature combustion, Rock-Eval pyrolysis and gas analysis were used to analyze oil shale from Babouri-Figuil Basin. Results show that the average content of organic matter is $36.25 \% \mathrm{wt}$, while that of mineral matter is $63.75 \% \mathrm{wt}$. The total organic carbon (TOC) is between $15.93 \%$ wt and $26.82 \%$ wt. The HI vs. $\mathrm{T}_{\max }$ diagram indicates an immature Type I kerogen. The average value of the oil potential $\left(S_{2 b}\right)$ is $149.95 \mathrm{mg} \mathrm{HC} / \mathrm{g}$ rock. The gases obtained by retort process are $\mathrm{H}_{2}, \mathrm{CO}_{2}, \mathrm{CO}$ and $\mathrm{C}_{n} \mathrm{H}_{2 n}, \mathrm{C}_{n} \mathrm{H}_{2 n+2}$. Finally, it emerges that, the organic matter of Babouri-Figuil shales was immature or has just reached the beginning of the oil window. The mineralogical study of Babouri-Figuil oil shale has been carried out by means of XRD (X-Ray Diffractometry) and XRF (X-Ray Fluorescence spectrometry). The results show that mineral matrix contains silica, carbonates, sulphates, oxides and clay minerals. Besides, compounds contain metals and metalloids like $\mathrm{Fe}$, In, Ca. The main oxides are $\mathrm{SiO}_{2}$ (majority), $\mathrm{CaO}, \mathrm{Fe}_{2} \mathrm{O}_{3}, \mathrm{Al}_{2} \mathrm{O}_{3}, \mathrm{SO}_{3}$, and $\mathrm{K}_{2} \mathrm{O}$.
\end{abstract}

\footnotetext{
"Corresponding author.

How to cite this paper: Nyangono Abolo, A.J., Ngos III, S., Balla Ondoa, A.D., Garcia, B., Fernanda-Sarmiento, M., Mbesse, O.C., Abolo, G.M., Eloung Nna, D.M., Nkengfack, A.E., Ndjeng, E. and Qian, J. (2014) Geochemical Characterization and Mineralogy of Babouri-Figuil Oil Shale, North-Cameroon. Journal of Surface Engineered Materials and Advanced Technology, 4, 359-368. http://dx.doi.org/10.4236/jsemat.2014.46040
} 


\section{Keywords}

\section{Oil Shale, Babouri-Figuil, Organic Matter, Mineral Matter, Rock-Eval Pyrolysis, X-Ray Diffractometry, X-Ray Fluorescence Spectrometry}

\section{Introduction}

As the overall situation of conventional oil and gas resources becomes increasingly severe, oil shale resources begin to be paid more and more attention. Since oil shale is characterized by beneficial features, economic values and large resources, it is considered as an important substitution resource for the $21^{\text {st }}$ century [1] [2].

In Cameroon, one of the main deposits of oil shale is localized in the Cretaceous Basin of Babouri-Figuil, North Region, precisely in the Mayo Figuil and Mayo Tafal series (or outcrops). Due to the economic and scientific interest of this resource, the Laboratory of Petroleum and Sedimentary Geology of University of Yaounde I-Cameroon has decided to study these oil shale formations.

The aim of this study is to give the organic and inorganic composition of Babouri-Figuil oil shale and to characterize their organic matter. All the information has been obtained by high temperature combustion method, Rock-Eval pyrolysis, gas analysis, XRD and XRF.

\section{Geological Setting}

The Babouri-Figuil Basin is one among the numerous lower Cretaceous intra-continental small basins of Northern Cameroon (Figure 1) and belongs, like the Benue trough, to the West and Central African Rift Systems (WCARS), linked to the opening of the Southern Atlantic Ocean [3]-[7]. The structure of this basin is half-graben and consists of a synclinal feature that has an East-West extension [5] [8]. The total surface is about 251 $\mathrm{km}^{2}$. In terms of sedimentary succession, the Neocomian-Barremian series (with a maximum thickness of 1500 $\mathrm{m})$ begins with breccias, conglomerates, micro-conglomerates, sandstones, claystones and arkoses. Above those layers, clays, marls and sandstones occur in alternance. The series lie unconformably on a granitic basement and is cross-cut by volcanic rocks and plutonic intrusions [8]-[10]. The depositional environment in the BabouriFiguil basin is lacustine and/or fluvial-lacustrine [5] [7] [8].

In this basin, the oil shales have been discovered in two series, Mayo Figuil and Mayo Tafal [5] [8]. From the sedimentological and environmental viewpoint, it emerges that, the lithology of the two series are nearly similar and consists of conglomerates, sandstones, limestones, clays, schistose marls (abundant) and oil shales all restful on a

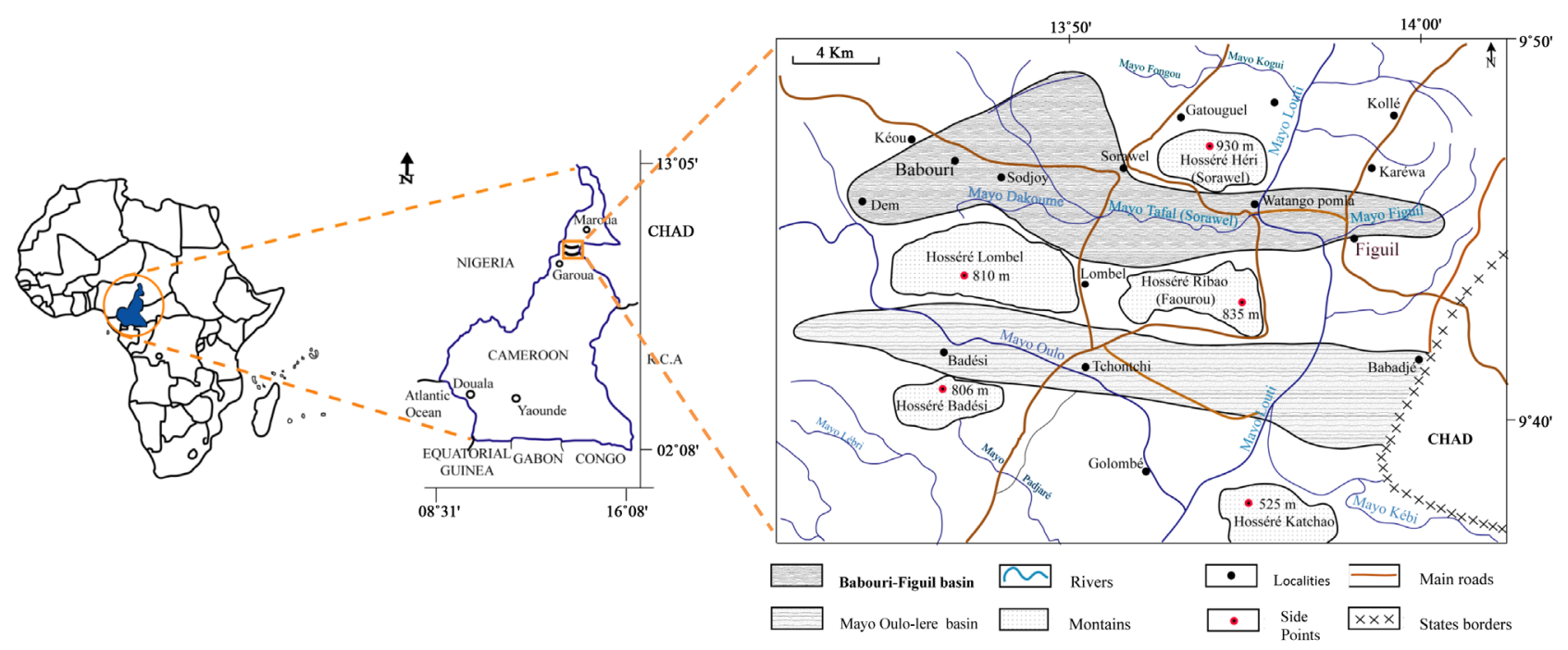

Figure 1. Location of Babouri-Figuil Basin. Adapted from [5]. 
crystalline plinth (Figure 2). In the Mayo Figuil series, the oil shale beds occur at in the top of the series, while in the Mayo Tafal series, they occur from the bottom to the top.

The oil shale deposits consist of numerous black or grey coloured beds, with the thicknesses of a few centimeters to about tenths of meters. These layers outcrop at the surface and disappear at the depth. They cut up either into rocky leaf or in small parts of rocks.

\section{Sampling, Materials and Methods}

In the Babouri-Figuil Basin, two representative oil shale samples (F1, F2) were obtained from Mayo Figuil series (Figure 3(a), Figure 3(b)) and two others (T1, T2) came from Mayo Tafal series (Figure 4(c), Figure 4(d)). Those samples were tested and analyzed.

The methods have consisted in crushing, grinding and sieving to yield samples with a particle size of $75 \mu \mathrm{m}$.

In order to study the content and composition of mineral matter, organic matter was prior removed [1]. In our case we used high temperature combustion method; which consisted in burning the rock powder at $550^{\circ} \mathrm{C}$ in the furnace. Following this operation, the shale ash obtained was analyzed by XRD, whereas oil shale powder which was obtained by crushing and grinding was analyzed by XRF. XRD was carried out by the AGEs Laboratory of the University of Liege-Belgium, whereas XRF has been realized at the MIPROMALO and CAPAM Laboratories (Cameroon Mining and Material Laboratories).

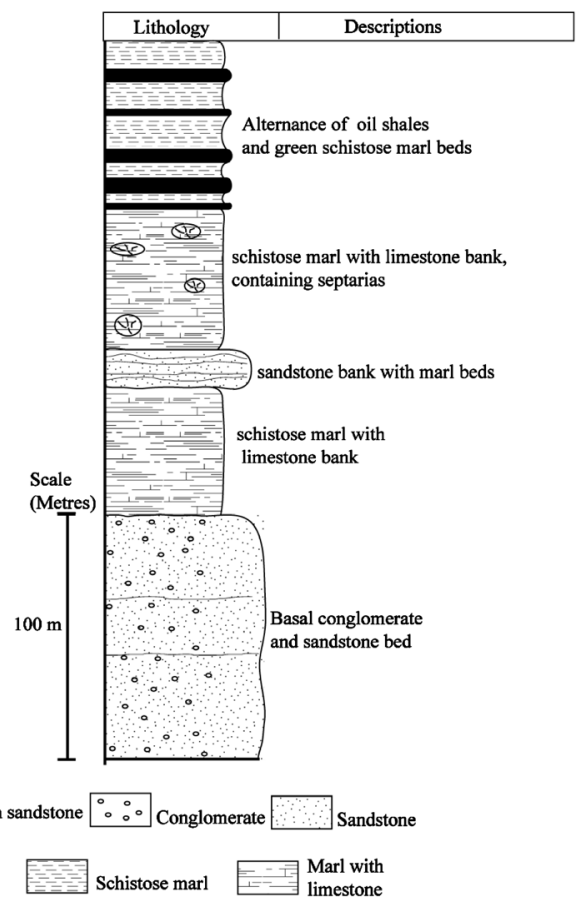

(a)

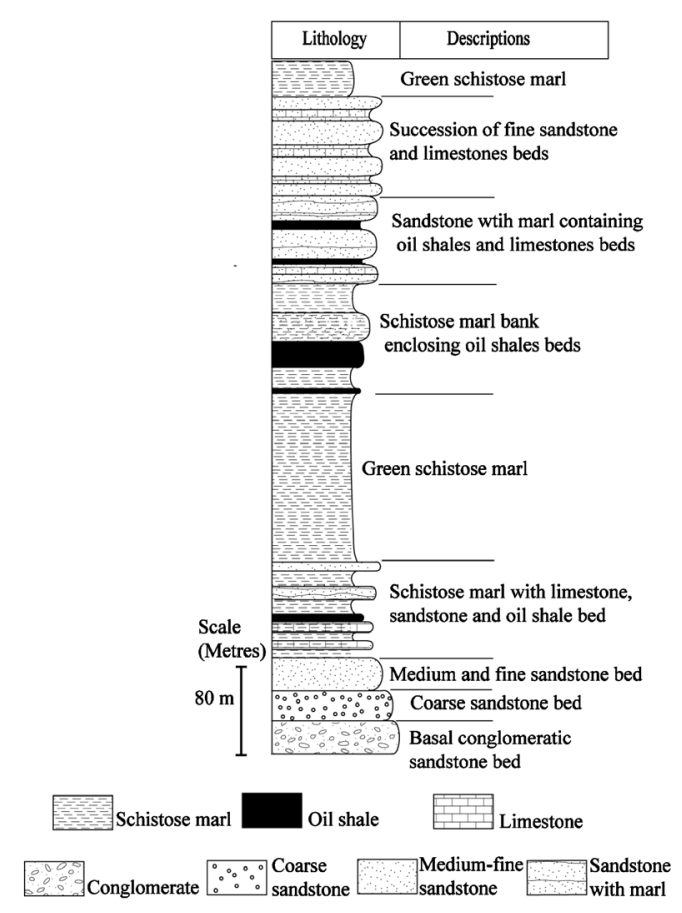

(b)

Figure 2. (a) Graphic log of Mayo Figuil series; (b) Graphic log of Mayo Tafal series.

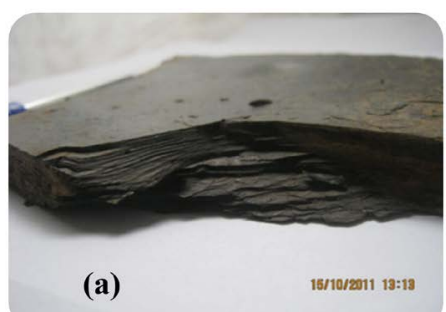

Figure 3. Oil shale of Babouri-Figuil Basin: Mayo Figuil samples ((a) $=\mathrm{F} 1$ and $(\mathrm{b})=\mathrm{F} 2$ ).

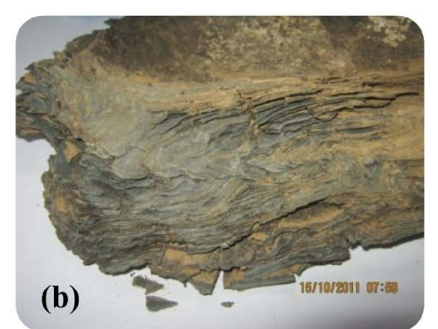

(b) 

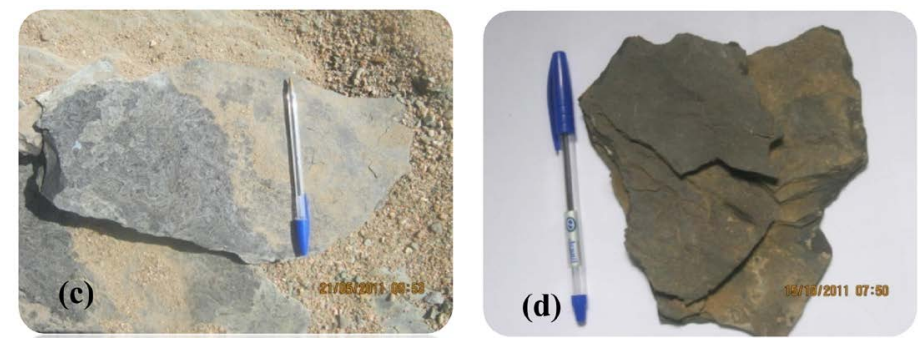

Figure 4. Oil shale of Babouri Figuil basin: Mayo Tafal samples ((c) $=\mathrm{T} 1$ and $(\mathrm{d})=\mathrm{T} 2)$.

Concerning the study of the organic matter, the mineral matrix content was also prior removed. For this operation, Babouri-Figuil oil shales were treated repeatedly with $\mathrm{HCl}(6 \mathrm{~N}), \mathrm{HCl}(4 \mathrm{~N})$ and $40 \% \mathrm{HF}(\mathrm{HCl}$ was used for mineral carbonates removal, and HF for removal of mineral oxides and silicates) [1] [11].

The Rock-Eval instrument was developed at IFPEN (former Institut Français de Pétrole (IFP)) in 1977 [12][14]. The method consists in estimating petroleum potential of rock samples by pyrolysis according to a programmed temperature pattern [15]. Rock-Eval analyses were performed at the geochemistry-petrophysics department of IFPEN, using a Rock-Eval 6 device.

The "reservoir method" was used to analyze these samples and this method consists to perform firstly a pyrolysis cycle starting from $180^{\circ} \mathrm{C}$ (initial temperature during $10 \mathrm{~min}$ ) to $650^{\circ} \mathrm{C}$ using a heating rate equal to $25^{\circ} \mathrm{C} / \mathrm{min}$ and, secondly, an oxidation cycle from $300^{\circ} \mathrm{C}$ to $850^{\circ} \mathrm{C}$ at a temperature rate equal to $25^{\circ} \mathrm{C} / \mathrm{min}$.

From this method, the following parameters were obtained $\mathrm{S}_{1 \mathrm{r}}, \mathrm{S}_{2 \mathrm{a}}, \mathrm{S}_{2 \mathrm{~b}}, \mathrm{TOC}, \mathrm{T}_{\max }$, HI and OI, among others.

$\mathrm{S}_{1 \mathrm{r}}=$ lightest free or sorbed hydrocarbons; $\mathrm{S}_{2 \mathrm{a}}=$ heavier free or sorbed hydrocarbons; $\mathrm{S}_{2 \mathrm{~b}}=$ hydrocarbons potentially generated from thermal maturation of sedimentary organic matter (kerogen); TOC = total organic carbon; $\mathrm{T}_{\max }=$ temperature of the maximum of S2b peak; $\mathrm{HI}=$ hydrogen index and $\mathrm{OI}=$ oxygen index.

The gas analysis has been performed at the China University of Petroleum (Beijing). Oil shale was crushed and heated to approximately $520^{\circ} \mathrm{C}$ by direct contact with heated ceramic balls. At this temperature, the organic matter in oil shale rapidly decomposes to produce hydrocarbon vapor. Subsequent cooling of this vapor yields crude oil shale and light hydrocarbon gases [16].

\section{Results and Discussion}

\subsection{High Temperature Combustion}

The percentage of mineral and organic matter can be easily obtained by the high temperature combustion method. In fact, during the heating of raw oil shale at $550^{\circ} \mathrm{C}$, the mass loss is attributed mostly to the removal of organic matter, while the remaining material (shale ash), can be considered as the mineral matter [17]. The usual formula used for the determination of the organic matter percentage is:

$$
\text { Loi550 }=\frac{\text { dry mass }-550 \text { mass }}{\text { dry masse }} * 100
$$

where, dry mass is the initial weight of the oil shale sample (g), and 550 mass is the sample weight at the end of the combustion of organic matter (g).

It's known that, oil shale sample constituted by organic and mineral matter, and then the equation of the total mass (wt\%) of raw oil shale material can be written as:

$$
\text { Mineral matter }(w t \%)+\text { organic matter }(w t \%)=\text { raw oil shale }(100 w t \%)
$$

Note that, organic matter $=$ Loi550.

The Table 1 shows the different percentage of mineral and organic matter giving by high temperature combustion method for the Babouri-Figuil oil shale.

The mineral matter content in Babouri-Figuil samples is between $55 \% \mathrm{wt}-73 \% \mathrm{wt}$ and the average value is $63.75 \% w t$; while the organic matter content is between $27 \% \mathrm{wt}$ - $45 \% \mathrm{wt}$, for an average value of $36.25 \% \mathrm{wt}$. Concerning the organic matter, all the samples show a percentage greater than $10 \%$ wt meaning that the rock 
Table 1. Characteristics of the initial samples, \%.

\begin{tabular}{ccc}
\hline Oil shale samples & Mineral matter \% & Organic matter \% \\
\hline F1 & 60 & 40 \\
F2 & 67 & 43 \\
T1 & 55 & 27 \\
T2 & 73 & 36.25 \\
\hline
\end{tabular}

samples analyzed belong to the oil shale group. In comparison, the results obtained by high temperature combustion method for the Fushun and Maoming oil shale in China are respectively $72.2 \%$ wt of mineral matter and $27.8 \%$ wt of organic matter; and $71.9 \%$ wt of mineral matter and $28.1 \% w t$ of organic matter [1]-[18]. These data show that, the ratio of organic matter in Fushun and Maoming oil shale is lower than those of Babouri-Figuil Basin. It is the same case for the German Dotternhausen samples which show an organic matter ratio of 8.8. With a ratio of $50.5 \%$ wt, the organic matter of Kukersite oil shale in Estonia is higher than the one of Babouri-Figuil oil shale (see Table 2).

\subsection{Rock-Eval Pyrolysis}

Organic matter abundance, type, thermal maturity and hydrocarbon potential of rock samples can be investigated by Rock-Eval pyrolysis [2]. The results are summarized in the Table 3.

The TOC content of Babouri-Figuil oil shale varies between $15.93 \% w t-26.82 \% w t$, with an average value of $21.08 \%$ wt. Samples show TOC values greater than $15 \%$ wt, meaning that samples are organic matter-rich rocks. The average TOC content of Mayo Tafal samples is $21.4 \% w t$, whereas the average TOC content of Mayo Figuil samples is $20.8 \% w t$, it emerges that, the TOC content in Mayo Tafal samples is slightly higher than that the one of Mayo Figuil. These high values of TOC are assigned to favorable environment of production and preservation of the organic matter.

The free or sorbed hydrocarbons $\left(\mathrm{S}_{1 \mathrm{r}}+\mathrm{S}_{2 \mathrm{a}}\right)$ in the samples vary between 3.32 and $14.85 \mathrm{mg} \mathrm{HC} / \mathrm{g}$ rock, for an average value of $7.51 \mathrm{mg} \mathrm{HC/g} \mathrm{rock.}$

The oil potential $\left(\mathrm{S}_{2 \mathrm{~b}}\right.$ ) ranges from 121.58 to $199.42 \mathrm{mg} \mathrm{HC} / \mathrm{g}$ rock in the Mayo Tafal series and, from 127.54 to $151.27 \mathrm{mg} \mathrm{HC} / \mathrm{g}$ rock in the Mayo Figuil. The value is $149.95 \mathrm{mg} \mathrm{HC} / \mathrm{g}$ rock. These $\mathrm{S}_{2 \mathrm{~b}}$ values indicate that, oil shale samples from Babouri-Figuil have a strong tendency to hydrocarbons generation. The HI of all the samples is more than $650 \mathrm{mg} \mathrm{HC} / \mathrm{g} \mathrm{TOC}$; and the OI value of the samples is between $9.47-11.99 \mathrm{mg} \mathrm{CO} / \mathrm{g}$ TOC. High HI and low OI values in Babouri-Figuil oil shale samples reflect a sapropelic organic content.

The Rock-Eval $\mathrm{T}_{\max }\left(422^{\circ} \mathrm{C}-435^{\circ} \mathrm{C}\right)$ indicate that, organic matter of Babouri-Figuil shales is immature or has just reached the beginning of the oil window.

The Rock-Eval $\mathrm{HI}$ and $\mathrm{T}_{\max }$ are important parameters reflecting the type and evolution of organic matter [19] [20]. The HI vs. $\mathrm{T}_{\max }$ diagram classifies the kerogen of Babouri-Figuil oil shale as Type I kerogen (Figure 5), indicating a lacustrine environment associated to anaerobic conditions.

This domination of Type I kerogen indicates that, Babouri-Figuil oil shale has a high oil generating potential. Usually, the Type I kerogen is derived essentially from algal material and terrestrial bacteria [21] [22]. Probably, the cyanophyceae (blue-green algal) identified by [7] in the basin, is the main algal type which constitutes the organic matter content of Babouri-Figuil oil shale.

\subsection{Gas Analysis}

The composition of retort gas of Babouri-Figuil oil shale produced by Chinese retorts processing is shown in Table 4. From this table, the gas contains is as follows: $34.70 \% \mathrm{H}_{2}, 19.74 \% \mathrm{CO}_{2}$, and $5.74 \% \mathrm{CO}$. The $\mathrm{C}_{\mathrm{n}} \mathrm{H}_{2 \mathrm{n}}$ gaseous hydrocarbons are between $1.51 \%-3.07 \%$, for a total of $9.68 \%$. The $\mathrm{C}_{\mathrm{n}} \mathrm{H}_{2 \mathrm{n}+2}$ gaseous hydrocarbons vary between $0.63 \%-18.53 \%$, for a total of $30.24 \%$, and the high value $(18.53 \%)$ belongs to methane $\left(\mathrm{CH}_{4}\right)$. From oil shale retorting gas, hydrocarbons represent about $40 \%$ of the total gaseous compounds. 


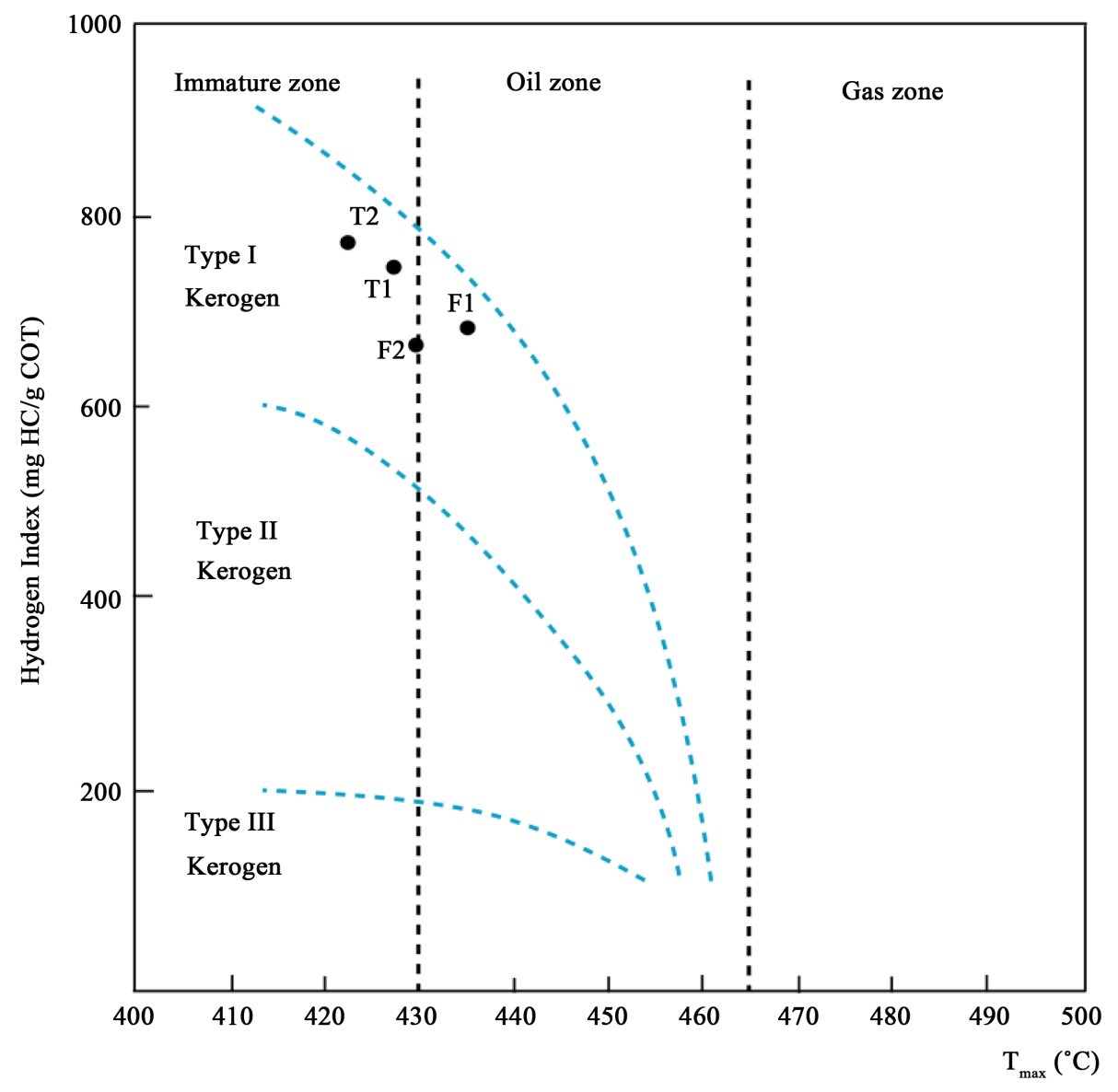

Figure 5. Relationship between $\mathrm{HI}$ and $\mathrm{T}_{\max }$ showing the position of the four Babouri-Figuil oil shales.

Table 2. Comparative organic and mineral matter ratios of Fushun, Maoming, Dotternhausen, Kukersite, and Babouri-Figuil oil shale.

\begin{tabular}{cccc}
\hline Oil shale samples & Organic matter (\%) & Mineral matter (\%) & References \\
\hline Fushun & 27.8 & 72.2 & {$[1]$} \\
Maoming & 28.1 & 71.9 & {$[1]$} \\
Dotternhausen & 8.8 & 91.9 & {$[24]$} \\
Kukersite & 50.5 & 49.5 & 63.75 \\
Babouri-Figuil & 36.25 & & - \\
\hline
\end{tabular}

Table 3. Rock-Eval data of Babouri-Figuil oil shale.

\begin{tabular}{|c|c|c|c|c|c|c|c|c|}
\hline $\begin{array}{l}\text { Oil shale } \\
\text { samples }\end{array}$ & $\mathrm{T}_{\max },\left({ }^{\circ} \mathrm{C}\right)$ & TOC, (\%) & $\begin{array}{c}\mathrm{S}_{1 \mathrm{r}}, \\
\mathrm{mg} \mathrm{HC} / \mathrm{g} \text { rock }\end{array}$ & $\begin{array}{c}\mathrm{S}_{2 \mathrm{a}}, \\
\mathrm{mg} \mathrm{HC} / \mathrm{g} \text { rock }\end{array}$ & $\begin{array}{c}\text { HC free, } \\
\text { mg HC/g rock }\end{array}$ & $\begin{array}{c}\mathrm{S}_{2 \mathrm{~b}}, \\
\mathrm{mg} \mathrm{HC/g} \mathrm{rock}\end{array}$ & $\begin{array}{c}\text { HI, } \\
\text { mg HC/g TOC }\end{array}$ & $\begin{array}{c}\text { OI, } \\
\mathrm{mg} \mathrm{CO}_{2} / \mathrm{g} \text { TOC }\end{array}$ \\
\hline $\mathrm{F} 1$ & 435 & 22.28 & 0.12 & 3.2 & 3.32 & 151.27 & 679 & 9.47 \\
\hline $\mathrm{F} 2$ & 430 & 19.29 & 0.27 & 4.88 & 5.15 & 127.54 & 661 & 10.01 \\
\hline $\mathrm{T} 1$ & 427 & 26.82 & 1.28 & 13.57 & 14.85 & 199.42 & 744 & 10.29 \\
\hline $\mathrm{T} 2$ & 422 & 15.93 & 0.33 & 6.38 & 6.71 & 121.58 & 763 & 11.99 \\
\hline
\end{tabular}


Table 4. Composition of Babouri-Figuil oil shale retorts gas.

\begin{tabular}{|c|c|c|c|}
\hline \multicolumn{2}{|c|}{ Component } & \multicolumn{2}{|c|}{ Composition, vol\% } \\
\hline $\mathrm{CO}_{2}$ & & & 19.74 \\
\hline \multirow[t]{5}{*}{$\mathrm{C}_{\mathrm{n}} \mathrm{H}_{2 \mathrm{n}}$} & & & 9.68 \\
\hline & $\mathrm{C}_{5} \mathrm{H}_{10}$ & 1.51 & \\
\hline & $\mathrm{C}_{4} \mathrm{H}_{8}$ & 2.02 & \\
\hline & $\mathrm{C}_{3} \mathrm{H}_{6}$ & 2.98 & \\
\hline & $\mathrm{C}_{2} \mathrm{H}_{4}$ & 3.07 & \\
\hline $\mathrm{CO}$ & & & 5.74 \\
\hline $\mathrm{H}_{2}$ & & & 34.70 \\
\hline \multirow[t]{7}{*}{$\mathrm{C}_{\mathrm{n}} \mathrm{H}_{2 \mathrm{n}+2}$} & & & 30.24 \\
\hline & $\mathrm{CH}_{4}$ & 18.53 & \\
\hline & $\mathrm{C}_{2} \mathrm{H}_{6}$ & 7.11 & \\
\hline & $\mathrm{C}_{3} \mathrm{H}_{8}$ & 2.78 & \\
\hline & $\mathrm{C}_{4} \mathrm{H}_{10}$ & 1.19 & \\
\hline & $\mathrm{C}_{5} \mathrm{H}_{12}$ & 0.63 & \\
\hline & & & 100 \\
\hline
\end{tabular}

These gases can also be classified into two groups according to their carbon and hydrogen atoms numbers. The first group is light gas which consists of $\mathrm{CO}, \mathrm{CO}_{2}, \mathrm{H}_{2}, \mathrm{CH}_{4}$ and $\mathrm{C}_{2} \mathrm{H}_{4}$. The second group is the heavy gas which is made up of $\mathrm{C}_{2}(10.18 \%), \mathrm{C}_{3}(5.76 \%), \mathrm{C}_{3}(3.21 \%)$ and $\mathrm{C}_{5}(2.14 \%)$ hydrocarbons, and consists of $\left(\mathrm{C}_{2} \mathrm{H}_{6}\right.$, $\mathrm{C}_{3} \mathrm{H}_{6}, \mathrm{C}_{3} \mathrm{H}_{8}, \mathrm{C}_{4} \mathrm{H}_{8}, \mathrm{C}_{4} \mathrm{H}_{10}, \mathrm{C}_{5} \mathrm{H}_{10}, \mathrm{C}_{5} \mathrm{H}_{12}$ ).

The oil shale retort gas includes many interesting and potentially valuable components. These range from simple fuel compounds like methane to more exotic compounds such as butylene, propylene and ethylene [23].

\subsection{X-Ray Diffractometry}

The results of four oil shale samples of Babouri-Figuil Basin show that their mineralogy consists of silica (quartz, feldspars, analcime, wairakite), carbonates (calcite, dolomite), sulphates (pyrite, carlinite, cooperite), oxides (anatase) and clay minerals. The clay minerals identified are kaolinite, smectite, montmorillonite, illite, chlorite and tarasovite (composed clay).

The mineral matter in oil shale can be divided into three types according to its source. The first type is the mineral matter originally existing in planktons and vegetables, the remnants of which became the mineral matter of oil shale, such as silicon oxide from bacillariophycene and calcium oxide from shells. The second type is the mineral matter derived from dismantling of surrounding relief and infiltrated into oil shale during its formation, or some was carried by rivers and underground water into lakes, where oil shale was formed. The third type is the mineral matter which is formed during the chemical reaction occurring inside the sediment. The first and third types are regarded as intrinsic mineral matter, while the second type is called extrinsic mineral matter [1].

The mineral matter of Babouri-Figuil oil shale may probably be derived by those three sources. In this way, some minerals are derived from rock alteration and were deposited in the basin after transport whereas others are formed directly within the sedimentary basin. This last group is called authigenous mineral and it may be the case of carbonates mineral in Babouri-Figuil Basin. 


\subsection{X-Ray Fluorescence Spectrometry}

The XRF analysis permits to obtain the chemical composition of Babouri-Figuil oil shale. It emerges from Table 5 that, the main oxides are $\mathrm{SiO}_{2}$ (57.95\%), $\mathrm{CaO}$ (11.51\%), $\mathrm{Fe}_{2} \mathrm{O}_{3}(7.25 \%), \mathrm{Al}_{2} \mathrm{O}_{3}(6.4 \%), \mathrm{SO}_{3}(4.15 \%), \mathrm{K}_{2} \mathrm{O}$ (2.45\%), $\mathrm{Na}_{2} \mathrm{O}(0.5 \%)$ and $\mathrm{TiO}_{2}(0.3 \%)$. Beside, the same Table 5 [1] (modified) shows that, the composition of Babouri-Figuil oil shale is close to the Fushun and Maoming one regarding the high silicon oxide $\left(\mathrm{SiO}_{2}\right)$ contents and the low calcium and magnesium oxides contents ( $\mathrm{CaO}, \mathrm{MgO}$ respectively). This is due to the oil shale formation conditions in ancient age and can also be related to the current climate conditions that causes the loss of $\mathrm{Ca}$ and $\mathrm{Mg}$ and the concentration of $\mathrm{Al}$ and $\mathrm{Fe}$ [1].

Spectrometer was also used to determine the elements contents of Babouri-Figuil oil shale and the results are summarized in Table 6. The main elements found in the basin are iron (Fe) with content varying between $2 \%$ 6.85\%; calcium (Ca) with content varying $0.75 \%-3.1 \%$ and indium (In) with content varying $0.12 \%-45.01 \%$. Potassium $(\mathrm{K})$, titane $(\mathrm{Ti})$, cobalt $(\mathrm{Co})$, strontium $(\mathrm{Sr})$, copper $(\mathrm{Cu})$, zinc $(\mathrm{Zn})$ are also present but, in small amounts with the percentage comprised between $0.01 \%-0.12 \%$.

Those elements can be also divided into two groups. The first group includes only one macro nutritional elements, which is potassium (K). The second group is the heavy metal and metalloid and consists of iron (Fe), calcium (Ca), indium (In), titanium (Ti), cobalt (Co), strontium (Sr), copper (Cu) and zinc ( $\mathrm{Zn})$.

The presence of indium (In), with a rate of $45 \%$ in some oil shale samples can be a great opportunity for the mining sector in the Babouri-Figuil Basin.

\section{Conclusions}

The Babouri-Figuil Cretaceous Basin in North-Cameroon includes rich organic matter sediment. These sediments are named "oil shale". The host rocks are mainly claystone, in which organic matter is heterogeneously and finely dispersed. The current oil shale deposits are localized in Mayo Figuil and Mayo Tafal series. The organic geochemical and mineralogical methods used during this study have made their characterization possible. High temperature combustion method showed that, organic matter content varies from $27 \%$ wt to $45 \%$ wt, while mineral matter content is between $55 \%$ wt and 73 \%wt. The Rock-Eval analysis indicates that, the content of TOC is higher than $15 \%$ wt for the whole sample of the Basin. The average value is $21.08 \%$. The average value of the potential hydrocarbon is $149.95 \mathrm{mg} \mathrm{HC} / \mathrm{g}$ rock, and the average value of total free hydrocarbons is 7.51 mg HC/g rock. The $T_{\max }$ value of the entire sample is lower than $435^{\circ} \mathrm{C}$. The main kerogen is Type $\mathrm{I}$.

Table 5. Comparative chemical compositions of Fushun, Maoming, Green River, Kukersite, Dotterrnhausen, and BabouriFiguil oil shale.

\begin{tabular}{ccccccccccccc}
\hline Samples & $\mathrm{Fe}_{2} \mathrm{O}_{3}, \%$ & $\mathrm{Al}_{2} \mathrm{O}_{3}, \%$ & $\mathrm{SO}_{3}, \%$ & $\mathrm{SiO}_{2}, \%$ & $\mathrm{TiO}_{2}, \%$ & $\mathrm{SO}_{2}, \%$ & $\mathrm{CaO}, \%$ & $\mathrm{MgO}, \%$ & $\mathrm{~K}_{2} \mathrm{O}, \%$ & $\mathrm{Na}_{2} \mathrm{O}, \%$ & $\mathrm{O}$ thers \\
\hline Fushun & 6.15 & 28.02 & - & 58.04 & 1.17 & 1.81 & 1.35 & 0.91 & 1.41 & 1.14 & - \\
Maoming & 7.92 & 29.42 & - & 53.42 & 0.86 & 2.16 & 0.69 & 1.23 & 2.91 & 1.39 & - \\
Green River & 4.60 & 12.22 & - & 43.81 & - & 2.22 & 22.06 & 9.36 & 2.36 & 3.33 & - \\
Kukersite & 7.0 & 9.5 & - & 30.5 & 0.3 & 5.5 & 40.0 & 4.0 & 2.5 & 0.5 & - \\
Dotternhausen & 6.53 & 9.87 & 9.54 & 34.4 & - & - & 32.2 & 1.67 & - & - & - \\
Babouri-Figuil & 7.25 & 6.4 & 4.15 & 57.95 & 0.3 & - & 11.51 & - & 2.45 & 0.5 & 9.49 \\
\hline
\end{tabular}

Table 6. Contents of some metals and metalloids in Babouri-Figuil oil shale.

\begin{tabular}{|c|c|c|c|c|c|c|c|c|c|}
\hline Samples & $\mathrm{Fe} \%$ & Сa\% & In\% & $\mathrm{K} \%$ & Ti\% & Со\% & $\mathrm{Sr} \%$ & $\mathrm{Cu} \%$ & $\mathrm{Zn} \%$ \\
\hline $\mathrm{F} 1$ & 6.85 & 0.75 & - & - & 0.11 & 0.03 & 0.05 & 0.01 & 0.04 \\
\hline F2 & 2.43 & 3.1 & 0.12 & 1.0 & 0.05 & - & 0.07 & 0.01 & 0.01 \\
\hline $\mathrm{T} 1$ & 2 & 1.57 & - & - & 0.02 & 0.15 & 0.04 & 0.03 & 0.01 \\
\hline $\mathrm{T} 2$ & 3.2 & 2.1 & 45.01 & - & 0.12 & 0.01 & 0.06 & 0.01 & 0.01 \\
\hline
\end{tabular}


All those parameters indicate that, Babouri-Figuil oil shale is a good source rock, but has not the required temperature to generate hydrocarbons. The composition of Babouri-Figuil oil shale retort gas consists of $34.70 \% \mathrm{H}_{2}$, $19.74 \% \mathrm{CO}_{2}$, and $5.74 \% \mathrm{CO}$. The content of $\mathrm{C}_{\mathrm{n}} \mathrm{H}_{2 \mathrm{n}}$ gaseous hydrocarbons is $9.68 \%$, whereas the content of the $\mathrm{C}_{\mathrm{n}} \mathrm{H}_{2 \mathrm{n}+2}$ gaseous hydrocarbons is $30.24 \%$.

The organic matter of these shales is derived from planktonic biomass (lacustrine origin), probably associated with a bacterial and terrestrial material.

The mineralogical study shows that, the mineral matter composition of Babouri-Figuil oil shale consists of a variety of minerals, like silica, carbonates, sulphates, oxides and clay minerals. Besides, compounds containing $\mathrm{Fe}, \mathrm{In}, \mathrm{Ca}$, etc. $\mathrm{K}, \mathrm{Ti}, \mathrm{Co}, \mathrm{Sr}, \mathrm{Zn}, \mathrm{Cu}$ are also sometimes present in small amounts. The main oxides are $\mathrm{SiO}_{2}, \mathrm{CaO}$, $\mathrm{Fe}_{2} \mathrm{O}_{3}, \mathrm{Al}_{2} \mathrm{O}_{3}, \mathrm{SO}_{3}$, and $\mathrm{K}_{2} \mathrm{O} . \mathrm{Na}_{2} \mathrm{O}$ and $\mathrm{TiO}_{2}$ are also present.

Finally, the mineral matter of the Babouri-Figuil oil shale is derived from mineral matter originally existing in planktons and vegetables and mainly from dismantling of surrounding relief and chemical transformations that occurred during the sedimentation.

\section{Acknowledgements}

Authors are grateful for financial and material supports from the "University Commission for Development" (UCD) and University of Liege-Belgium (ULg). Thanks also to Geremie Letort (IFPEN) who carried out the Rock-Eval analysis, to Jialin Qian, Shuyuan Li and Yue Ma (China University of Petroleum) for the organization and realization of several analyses and documentation. Thank also to Shu Tao (China University of Mining and Technology) for the significant literature.

\section{References}

[1] Qian, J. and Yin, L. (2010) Oil Shale-Petroleum Alternative. China Petrochemical Press, Beijing, 619 p.

[2] Tao, S., Wang, Y.B., Tang, D.-Z., Xu, H., Zhang, B., He, W. and Liu, C. (2012) Composition of the Organic Constituents of Dahuangshan Oil Shale at the Northern Foot of Bogda Mountain, China. Oil Shale, 29, 115-127. http://dx.doi.org/10.3176/oil.2012.2.03

[3] Benkhelil, J. (1982) Benoue through and Benue Chain. Geological Magazine, 119, 155-168. http://dx.doi.org/10.1017/S001675680002584X

[4] Benkhelil, J. and Robineau, B. (1983) Is the Benue Trough a Rift? Bulletin of the Research Centers Exploration and Production. Elf Aquitaine, 7, 315-321.

[5] Ndjeng, E. (1992) Study of the Sedimentology and the Geodynamic Evolution Model of Two Lower Cretaceous Basins of North Cameroon: Babouri-Figuil and Mayo Oulo-Lere. Ph.D. Thesis, University of Yaounde, Yaounde, 280 p.

[6] Bessong, M., Abderrazak, E.A., Hell, J.V., Fontaine, C., Ndjeng, E., Ngos, S., Nolla, J.D., Dissombo, E., Mfoumbeng, M.P. and Mbang Bilongo, A.R. (2011) Diagenesis in Cretaceous Formations of Benue Trough in the Northern Part of Cameroon: Garoua Sandstones. World Journal of Engineering and Pure and Applied Science, 1, 58-67.

[7] Brunet, M., et al. (1988) Evidence of Early Barremian Age of Sedimentation in the Ditch of the Benue in West Africa (Mayo Oulo-Lere, Cameroon Basin) in Connection with the Opening of the South Atlantic. Review of the Academy of Sciences, Paris, 306, 1125-1130.

[8] Schwoerer, P. (1965) Explanatory Notes on the Sheet of Garoua East: Geological Map Recognition Scale 1/500000.

[9] Nzenti, J.P., Ngako, V., Kambou, R., Penaye, J., Bassahak, J. and Njel, O.U. (1992) Regional Structures of the PanAfrican Belt of Northern Cameroon. Review of the Academy of Sciences, Paris, 315, 209-215.

[10] Toteu, S.F., Penaye, J. and Poudjom Djomani, Y. (2004) Geodynamic Evolution of the Pan-African Belt in Central Africa with Special Reference to Cameroon. Canadian Journal of Earth Sciences, 41, 73-85. http://dx.doi.org/10.1139/e03-079

[11] Durand, B. and Nicaise, G. (1980) Procedures for Kerogen Isolation. In: Durand, B., Ed., Kerogen Insoluble Organic Matter from Sedimentary Rocks, Editions Technip, Paris, 35-53.

[12] Espitalie, J., Laporte, J.L., Madec, M., Marquis, F., Leplat, P., Paulet, J. and Boutefeu, A. (1977) Rapid Method for Characterizing the Source Rocks, Their Petroleum Potential and Their Degree of Evolution. Review of the French Petroleum Institute, 32, 23-42.

[13] Behar, F., Beaumont, V., De B. and Penteado, H.L. (2001) Rock-Eval 6 Technology: Performances and Developments. Oil \& Gas Science and Technology, Review of the French Petroleum Institute, 56, 111-134.

[14] Lafargue, E., Marquis, F. and Pillot, D. (1998) Applications of Rock-Eval 6 in the Exploration and Production of Hy- 
drocarbons, and in the Studies of Soil Contamination. Oil \& Gas Science and Technology, Review of the French Petroleum Institute, 53, 421-437.

[15] Johannes, I., Kruusement, K., Palu, V., Veski, R. and Bojesen-Koefoed, J. (2006) Evaluation of Oil Potential of Estonian Shales and Biomass Samples Using Rock-Eval Analyzer. Oil Shale, 23, 110-118.

[16] Lee, S. (2007) Shale Oil from Oil Shale. In: Handbook of Alternative Fuel Technology, CRC Press, Boca Raton, 223296.

[17] Tucker, M. (1988) Techniques in Sedimentology. Blackwell Scientific Publications, Oxford, 394 p.

[18] Qin, K.Z. (1982) Organic Mass Content and Its Ultimate Analysis of Fushun and Maoming Oil Shales. Journal of East China Petroleum Institute, 6, 71-79.

[19] Espitalie, J., Deroo, G. and Marquis, F. (1987) Rock-Eval Pyrolysis and Its Applications. Review of the French Petroleum Institute, 4, 73-88.

[20] Tissot, B.P. and Welte, D.H. (1984) Petroleum Formation and Occurrence. 2nd Edition, Springer-Verlag, Berlin, 699 p.

[21] Baudin, F., Tribovillard, N. and Trichet, J. (2007) Geology of the Organic Matter. Geological Society of France, Vuibert, Paris, 263 p.

[22] Tissot, B.P. and Welte, D.H. (1978) Petroleum Formation and Occurrence: A New Approach to Oil and Gaz Exploration. Springer-Verlag, Heidelberg, New York, 538 p.

[23] Soot, M.P., Voll, H. and Koiv, T.A. (2012) Utilization of Oil Shale Retort Gas. Oil Shale, 29, 248-267. http://dx.doi.org/10.3176/oil.2012.3.05

[24] Hilger, J. (2003) Combined Utilisation of Oil Shale Energy and Oil Shale Minerals, with the Production of Cement and Other Hydraulic Binders. Oil Shale, 20, 347-355. 
Scientific Research Publishing (SCIRP) is one of the largest Open Access journal publishers. It is currently publishing more than 200 open access, online, peer-reviewed journals covering a wide range of academic disciplines. SCIRP serves the worldwide academic communities and contributes to the progress and application of science with its publication.

Other selected journals from SCIRP are listed as below. Submit your manuscript to us via either submit@scirp.org or Online Submission Portal.
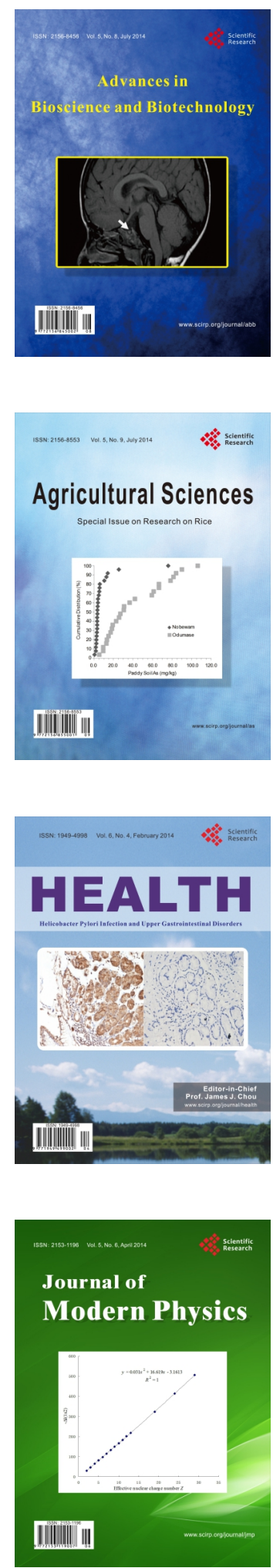
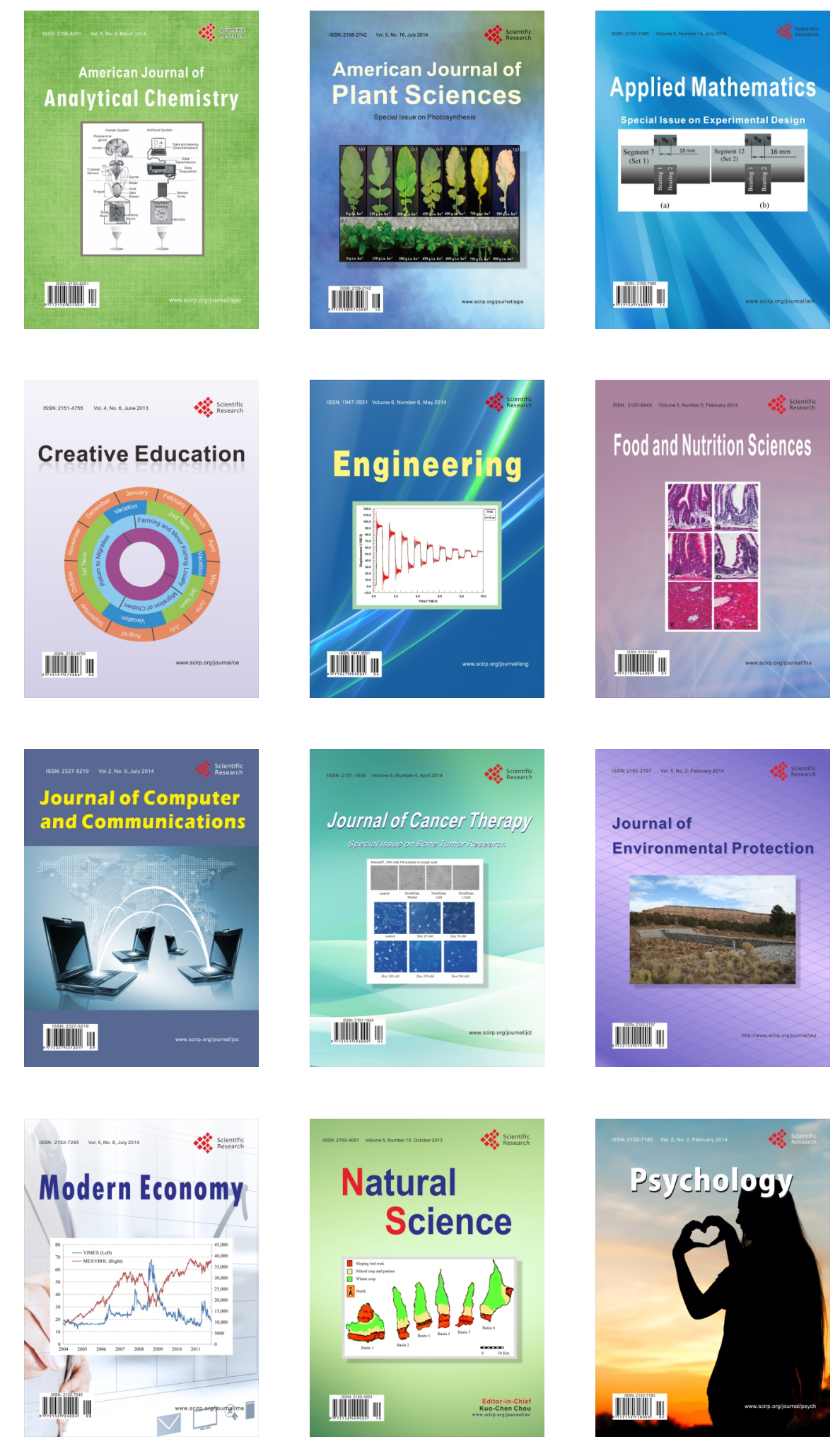